\title{
Survey of Purple Blotch Disease of Onion (Alternaria porri) of Allahabad District, India
}

\author{
Vinny John*, Sobita Devi Simon, Amit Kumar Maurya and Abhilasha A. Lal
}

Department of Plant Pathology, Sam Higginbottom University of Agriculture, Technology and Sciences, Allahabad (U.P.) - 211 007, India

*Corresponding author

\section{A B S T R A C T}

\begin{tabular}{|l|}
\hline Ke y w o r d s \\
$\begin{array}{l}\text { A. porri onion and } \\
\text { purple blotch }\end{array}$ \\
\hline Article Info \\
\hline $\begin{array}{l}\text { Accepted: } \\
\text { 04 September } 2018 \\
\text { Available Online: } \\
\text { 10 October } 2018\end{array}$ \\
\hline
\end{tabular}

\section{Introduction}

Onion (Allium cepa) belongs to family Alliaceae and genus Allium with about 300 species. Onion is one of the potential foreign exchange earners for a country like India, as it is second largest producer of onions after China. It contributes $19.25 \%$ of total world production (FAO, 2012). Though India ranks first in terms of the area under onion cultivation in the world and second in its production. It is one of the important ingredients of the daily diet facilitating a constant year round consumer demand. The productivity is still quite low as compared to other countries Anonymous, (2015). Onion crop is attacked by bacteria, fungi, nematodes, viruses, phytoplasma, phanerogamic plant
A survey was conducted in the onion growing fields of Allahabad district. For the survey ten villages viz., Hadha, Thanthanwa, Ghoorpur, Chaka, Pahlukapurwa, Karchana, Jari, Kanti, Soraon and Phoolpur were selected to evaluate the disease incidence of purple the lowest incidence of purple blotch was found in Phoolpur (4.12\%). The maximum was ) in Jari village followed by Karchana (15.37\%), Pahlukapurwa (14.87 record the disease incidence and isolation of the pathogen.

parasite and many other miscellaneous diseases and disorder. Among these diseases, the purple blotch (A. porri) is one of the major constrains in onion cultivation. The pathogen is polyphagus infecting crop like onion, garlic, shallot and other Allium crops. High relative humidity (80 to $90 \%)$ and optimum temperature $\left(24+2^{\circ} \mathrm{C}\right)$ are needed for further development of purple blotch disease symptoms causing considerable yield losses and is seed borne pathogen causing up to 2060 percent loss in bulb yield and extent of loss depends on time of infection and stage of crop growth. Shahanaz et al., (2007) reported losses of about 50 to 100 per cent with relative occurrence of $A$. porri. Typical symptoms of the disease appears on foliage and on foliage sheath small white sunken spots develop on 
the leaves which enlarge, become zonate and under moist conditions, turn purple and are also prominent on the inflorescence and stalks.

\section{Materials and Methods}

A survey was carried out during 2016 on onion crop during crop season to record the occurrence and distribution of purple blotch. Random survey was carried out in ten villages of Allahabad district viz., Hadha, Thanthanwa, Ghoorpur, Chaka, Pahlukapurwa, Karchana, Jari, Kanti, Soraon and Phoolpur. Eight farmer's field were selected in each village with plot size $\left(10^{2} \mathrm{~m}\right) .5$ diseased samples were collected from each plot for isolation and identification of blotchincidence.

\section{Isolation and identification}

The present study will be conducted in-vitro and field condition at Department of Plant pathology, Sam Higginbottom University of Agriculture, Technology and Sciences, during the rabi season. The infected leaf collected from the farmer's field to record the disease incidence and isolation of the pathogen. Sample washed in tap water and cut into small pieces $(2 \mathrm{~mm})$, surface sterilized with $0.1 \%$ mercuric chloride solution, thrice rinsed with sterilized distilled water, transferred aseptically into petri plates containing melted lukewarm $\left(45{ }^{\circ} \mathrm{C}\right)$ PDA medium and then small pieces of infected leaf will be kept aseptically on media inside Petri plates.

These Petri plates were incubated in BOD incubator at $28 \pm 1^{\circ} \mathrm{C}$. After $48 \mathrm{hrs}$ of inoculation, whitish colony growth of mycelium were observed in petri plates. From the periphery of this whitish colony growth a small bit will be taken and slide will be prepared using lacto phenol. The slide was observed under microscope for the further identification of pathogen.

\section{Calculation of disease incidence (DI)}

The percent disease incidence of wilt disease was calculated by using the formula:

$$
\begin{aligned}
& \text { Disease incidence } \%=\frac{\text { Total no. of infected plants }}{\text { Total no. of plants examined }} \times 100 \\
& \text { (Trapero-casas, 1983). }
\end{aligned}
$$

According to the scale described by Singh (2004) per cent of the surface of the leaf affected was determined. The infection on leaves was graded in 0-9 scale on the basis of severity/intensity/incidence of infection on leaves. The disease incidence was calculated with percentage ratio of infected area with the total area of leaf.

\section{Results and Discussion}

The systematic survey was conducted in 10 onion growing villages of Allahabad district during rabi season of 2016. The disease was prevalent at all the locations surveyed and the purple blotch disease incidence varied from minimum Phoolpur (4.12\%) to maximum Jari $(16.00 \%)$.

The highest followed by Karchana (15.37\%), Pahlukapurwa (14.87\%), Kanti (14.75\%), Thanthanwa (14.00\%), Ghoorpur (10.75\%), Hadha (9.62\%), Chaka (8.00\%) Soraon $(6.25 \%)$ respectively shown in the Table 1. Identification of morphological and pathogenic A. porri showed that purple blotch is present in maximum plots surveyed in the villages of Allahabad. The infected leaves were observed for purple blotch symptoms. The development of the initial symptoms starts from tip of the leaves particularly on older leaves and then spread to young leaves. Infected leaves showed small, whitish, sunken, oval shaped lesions to elliptical. The lesion was brown to purple at the centre. Concentric light and dark zones are also observed on the infected leaves. 
The scale for disease assessment was as follows

\begin{tabular}{|l|l|l|}
\hline SI. No. & $\begin{array}{l}\text { Percent leaf area } \\
\text { covered }\end{array}$ & $\begin{array}{l}\text { Grade } \\
(\mathbf{x})\end{array}$ \\
\hline 1. & 0 & 0 \\
\hline 2. & 1 & 1 \\
\hline 3. & $2-10$ & 3 \\
\hline 4. & $11-25$ & 5 \\
\hline 5. & $26-50$ & 7 \\
\hline 6. & $50>$ & 9 \\
\hline
\end{tabular}

Table.1 Survey of onion growing villages of Allahabad in 2016

\begin{tabular}{|c|c|c|c|c|c|c|c|c|c|c|c|}
\hline \multirow[t]{2}{*}{$\begin{array}{l}\text { Name of } \\
\text { villages }\end{array}$} & \multirow{2}{*}{$\begin{array}{l}\text { No. of } \\
\text { field } \\
\text { surveyed }\end{array}$} & \multirow{2}{*}{$\begin{array}{l}\text { No. of } \\
\text { diseased } \\
\text { plant in } \\
\text { each } \\
\text { field }\end{array}$} & \multicolumn{8}{|c|}{$\begin{array}{l}\text { No. of infected area }\left(10^{2} \mathrm{~m}\right) \text { in surveyed } \\
\text { fields }\end{array}$} & \multirow{2}{*}{\begin{tabular}{|l} 
Blotch \\
incidence \\
$(\%)$
\end{tabular}} \\
\hline & & & F1 & F2 & F3 & F4 & F5 & F6 & F7 & F8 & \\
\hline Hadha & 8 & 5 & 11 & 14 & 18 & 16 & --- & 8 & 10 & $\ldots$ & 9.62 \\
\hline Thanthanwa & 8 & 5 & 18 & 10 & 18 & 15 & 10 & 11 & 16 & 14 & 14.0 \\
\hline Ghoorpur & 8 & 5 & 17 & 18 & --- & 14 & 17 & 8 & $\ldots \ldots$ & 12 & 10.75 \\
\hline Chaka & 8 & 5 & --- & --- & 16 & --- & 18 & 12 & 18 & $\ldots$ & 8.00 \\
\hline Pahlukapurwa & 8 & 5 & 16 & 15 & 16 & 15 & 12 & 14 & 19 & 12 & 14.87 \\
\hline Karchana & 8 & 5 & 18 & 16 & 13 & 16 & 16 & 11 & 18 & 15 & 15.37 \\
\hline Jari & 8 & 5 & 18 & 16 & 13 & 17 & 16 & 18 & 12 & 18 & 16.00 \\
\hline Kanti & 8 & 5 & 18 & 14 & 16 & 18 & 15 & 16 & 9 & 12 & 14.75 \\
\hline Soraon & 8 & 5 & 18 & --- & --- & 17 & --- & 15 & $\ldots$ & $\ldots$ & 6.25 \\
\hline Phoolpur & 8 & 5 & 15 & --- & --- & 18 & --- & & ..... & $\ldots$ & 4.12 \\
\hline
\end{tabular}

Survey and collection of the diseased sample of purple blotch from farmer's field of Allahabad district

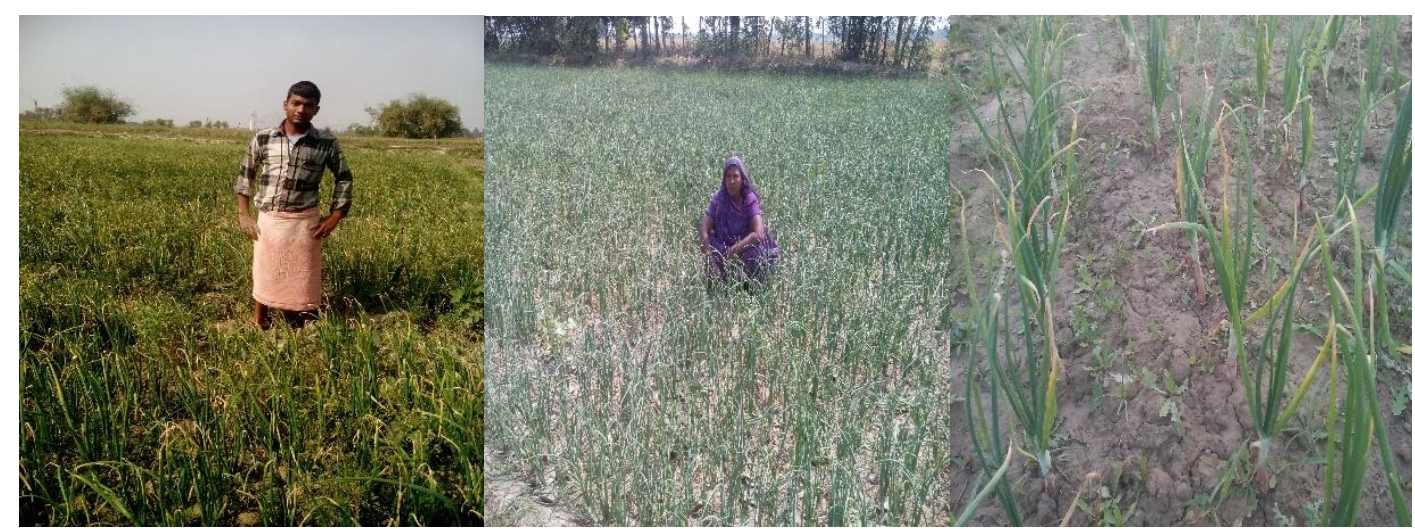




\section{Symptoms of purple blotch on onion}

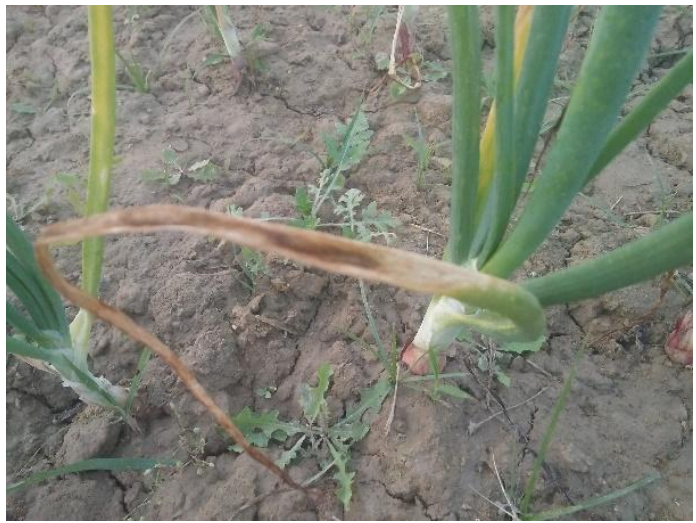

Change in colour of leaves was started from centre of the lesion which extended above and below the lesion further the lesion coalesce and spread rapidly on leaf blade and effected leaves showed drying. The symptoms were characteristic to that of purple blotch disease caused by Alternaria porri. The morphological study of the fungus was carried out on PDA. The white colonies turned into purple color with advancing age of culture. The observations were recorded on seven-days-old culture for the characters of the colony, mycelium, conidiophores and conidia and later their comparison with the characteristics described in the available literature (Barnett and Hunter, 1987; Singh, 1992).

\section{References}

Amresh, Y.S. (1997) Studies on foliar diseases of sunflower (Helianthus annus L.) with special reference to Alternaria leaf blight caused by Alternaria helianthi (Hansaf) Tubaki and Nishihara. M.Sc. (Ag.) Thesis, University of Agriculture Science, Dharwad.

Angell, H.R. 1929. Purple blotch of onion (Macrosporium porri Ell.). J. Agric. Res. 38: 467-487.

Anonymous, (2014-15) NHRDF; Nashik (www.nhrdf.com)
Conidia of $A$. porri

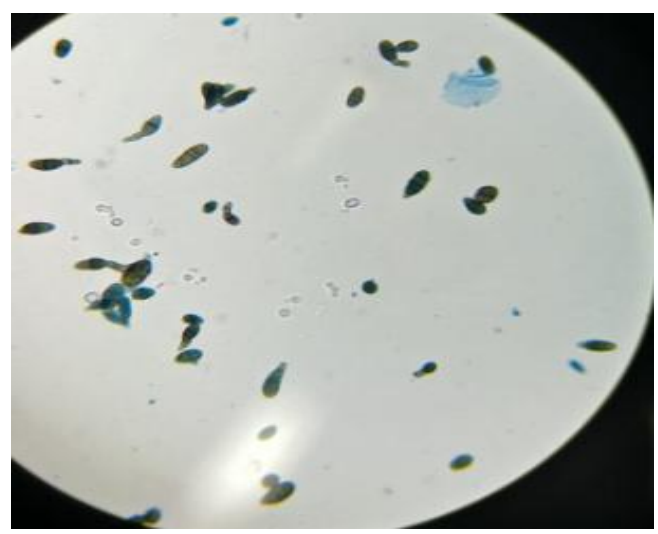

Anonymous, (2015). Government of India horticulture at a glance.pp.44-23.

Barnett, H.L. and B.B. Hunter (1987). Illustrated Genera of imperfect Fungi: Pub. C. New York, 218p.

Ciferri, R. (1930). Phytopathological survey of Santo Domingo, 1925-1929. J. Porto Rico, Dept. of Agric., 14:5-44.

Dubey, S.C. (2005). Influence of weather factors on development of Alternaria Blight J. Mycol Pl. Pathol, 35(2):369.

Ellis, M.B. and Holiday P. (1998). Alternaria porri (Descriptions of Fungi and Bacteria). IMI Descriptions of Fungi and Bacteria. 25: pp 248.

Everts, K.L., and Lacy, M.L. 1990. Influence of dew duration, relative humidity and leaf senescence on conidial formation and infection of onion by Alternaria porri. Phytopathology, 80:1203-1207.

NHRDF (2010). A brief report on onion crop damage due to rains. National Horticultural Research and Development Foundation, Nashik, M.S.

Panse, V.G. and P.V. Sukhatme (1978). Statistical Methods for Agricultural Workers, ICAR, New Delhi, Third Eddition, pp. 347.

Shrivastava P. K., Bhardwaj, B.S. and Gupta, P.P. (1994). Status of field disease and select pest of onion in India. Newsletter National Horti. Res. Dev. Foundation, 14: $11-14$ 
Shrivastava, P.K., Gupta R.P. Tiwari B.K. and Sharma R.C. (1996). A note on management of leaf blight disease of onion. Veg. Sci. 23(1):111-113.

Singh R. S. (1992). Disease of Vegetable Crops. Oxford and IBH Publishing Co. Pvt. Ltd. second Edition, pp. 287-289.
Suheri, H. and Price T.V. (2000). Infection of onion leaves by Alternaria porri and Stemphylium vesicarium and disease development in controlled environments. Plant Pathology. 49: 375-382.

\section{How to cite this article:}

Vinny John, Sobita Devi Simon, Amit Kumar Maurya and Abhilasha A. Lal. 2018. Survey of Purple Blotch Disease of Onion (Alternaria porri) of Allahabad District, India. Int.J.Curr.Microbiol.App.Sci. 7(10): 74-78. doi: https://doi.org/10.20546/ijcmas.2018.710.009 